\title{
Do nutrient availability and plant density limit seagrass colonization in the Baltic Sea?
}

\author{
Boris Worm*, Thorsten B.H. Reusch** \\ Institut für Meereskunde, Düsternbrooker Weg 20, 24105 Kiel, Germany
}

\begin{abstract}
Seagrasses continue to decline at an alarming rate throughout the planet's temperate regions. After a decline recolonization or restoration starts from small patches of single shoots which then propagate vegetatively. We investigated the effects of plant density within a patch and nutrient resources on growth and survival of eelgrass (Zostera marina $\mathrm{L}$.), the dominant seagrass species in the northern temperate zone. We created small $\left(0.5 \mathrm{~m}^{2}\right)$ eelgrass patches by planting single shoots in circular plots at high $(20 \mathrm{~cm})$ and low $(40 \mathrm{~cm}$ distance between shoots $)$ density. In a factorial design, the sediment was nutrient-enriched (1) through biodeposition of transplanted mussels (Mytilus edulis L.) (2) by a slowrelease NPK-fertilizer or (3) not enriched. The experiment was run over 1 growth period at a relatively nutrient-poor site $\left(<30 \mu \mathrm{mol} \mathrm{NH}{ }_{4}^{+}{ }^{-1}\right.$ porewater) in the Baltic Sea. Mussels increased $\mathrm{NH}_{4}{ }^{+}$concentrations and the fertilizer increased both $\mathrm{NH}_{4}{ }^{+}$and $\mathrm{PO}_{4}{ }^{3-}$ in the sediment porewater and the overlying water column, but this had only limited effects on eelgrass shoot growth rates and increase in shoot density, which were high overall (up to $75 \mathrm{~mm}$ shoot ${ }^{-1} \mathrm{~d}^{-1}$, doubling shoot density every $3 \mathrm{mo}$ ). In contrast, increased plant density had clear positive effects on shoot growth, areal expansion of patches and increase in shoot density. These results suggest that nutrient availability is not a major factor in eelgrass patch colonization or survival in the Baltic. Positive interactions among eelgrass shoots appear to be more important than competitive processes, during the early stages of recolonization.
\end{abstract}

KEY WORDS: Zostera marina - Patch dynamics - Restoration - Field experiment - Nitrogen · Nutrient limitation · Facilitation

\section{INTRODUCTION}

Seagrass beds are vital structural and functional components of nearshore ecosystems (den Hartog 1970, Orth 1992). Recent world-wide declines of seagrass abundance have alarmed ecologists and coastal managers (Orth \& Moore 1983, Giesen et al. 1990, Short \& Wyllie-Escheverria 1996). Detailed studies of recolonization processes, including dispersal, germination, 'growth, mortality and lateral expansion of newly established patches, are necessary to predict the resilience of seagrass populations after a decline and to restore

Present addresses:

*Biology Department, Dalhousie University, Halifax, Nova Scotia B3H 4J1, Canada. E-mail: bworm@is.dal.ca

* Max-Planck-Institut für Limnologie, August-ThienemannStr. 2, 24306 Plön, Germany viable populations through shoot transplantation (Orth et al. 1994, 1999, Harwell \& Orth 1999). Such studies are generally rare (Duarte \& Sand-Jensen 1990, Olesen $\&$ Sand-Jensen 1994a,b) and almost completely absent for the Baltic Sea, where a eutrophication-related decline of seagrasses and other macrophytes is in process on a basin-wide scale (Ciszewski et al. 1991, HELCOM 1996, Worm et al. 1999).

The importance of the early colonization period of land plants (Fenner 1992) and macroalgae (Worm \& Chapman 1998, Lotze et al. 2000) is well established but remains poorly understood in marine angiosperms. For established meadows, numerous studies have shown that seagrass growth is limited by the availability of $\mathrm{N}$ or $\mathrm{P}$ resources in the sediment porewater (reviewed by Short 1987, Worm et al. 2000). Very few studies have indicated a lack of nutrient limitation (but see critique by Worm et al, 2000), and artificial fertilization 
has been recommended for seagrass transplantation and restoration (Kenworthy \& Fonseca 1992, Sheridan et al. 1998). Based on comparisons of 4 uptake and growth studies, nitrogen limitation of Zostera growth was suggested to occur generally below concentrations of $100 \mu \mathrm{mol} \mathrm{NH}{ }_{4}^{+} \mathrm{I}^{-1}$ porewater (Dennison et al. 1987). In the Baltic, nutrient limitation of seagrasses (Zostera marina L.) has not been addressed directly, but there is evidence that frequently co-occurring mussels (Mytilus edulis L.) may fertilize shoot growth, overcoming nutrient limitation in nutrient-poor sediments (Reusch et al. 1994).

Eelgrass Zostera manina (Zostera hereafter), is the dominant seagrass species of the northern temperate zone, including the Baltic Sea (den Hartog 1970). We used a field experiment to investigate how initial plant density in a patch and the availability of nutrient resources shape patterns of eelgrass growth and colonization. This experiment served 2 main purposes: (1) to increase our understanding of patch dynamics during recolonization, and (2) to optimize transplantation techniques for restoration of eelgrass habitat in the Baltic Sea. Throughout 1 growth period, we quantified patterns of growth (shoot growth and increase in number of shoots), survival and areal expansion of artificially created Zostera patches in the Baltic Sea. We then tested whether experimental enhancement of porewater nutrients (through artificial fertilization or through mussel biodeposition) increases eelgrass growth at the initial stages of recolonization. Further, we manipulated plant density in a patch in order to test whether increased shoot density has an effect on eelgrass growth, possibly mediated through increased nutrient competition at low porewater levels (Williams 1987). Finally, we hypothesized possible interactions among these factors, which we tested through crossed manipulations in a factorial design.

\section{METHODS}

Study area. The experiment was run from May to December 1994 at Friedrichsort, Kiel Fjord, western Baltic Sea $\left(54^{\circ} 23^{\prime} \mathrm{N}, 10^{\circ} 12^{\prime} \mathrm{E}\right)$; for a detailed site description refer to Reusch et al. (1994). We chose this site because it is relatively protected, it supports shallow-water eelgrass meadows and mussels and because access to the site was restricted to our research vessel (thus human disturbance was reduced to a minimum). Although the site is protected against swells caused by the strong NW winds, wind from southerly direction ( 6 to $7 \mathrm{~km}$ fetch) can cause moderate wave action of 0.3 to $0.5 \mathrm{~m}$ height. Water temperature generally ranges from 0 to $4^{\circ} \mathrm{C}$ in winter and 18 to $24^{\circ} \mathrm{C}$ in summer; salinity fluctuates irregularly between 13 and 20 PSU. Thin sea ice often forms in January and February. The sediment consists of wellsorted, medium-grained silicate sand, which is poor in organic content $(0.42 \pm 0.1 \%$ loss of ignition, mean $\pm 1 \mathrm{SE}, \mathrm{n}=5$ ). Various sized patches of eelgrass occur between 1 and $4 \mathrm{~m}$ depth, but have their maximum extension at $2 \mathrm{~m}$ depth ( $44 \%$ coverage). Of the eelgrass patches at this depth, $39 \%$ have an understorey of mussels (Mytilus edulis; Reusch et al. 1994). The experiments were established at 2 to $2.2 \mathrm{~m}$ water depth using SCUBA. Patterns of photon flux density reaching the bottom at $2 \mathrm{~m}$ depth were quantified with an underwater quantum sensor (LI-COR 192S) and data logger (B. Schaffelke unpubl. data). Daily light sums between June and October were 3.12 to $27.5 \mathrm{~mol} \mathrm{~m}^{-2} \mathrm{~d}^{-1}(14.0 \pm 1.4$, mean $\pm \mathrm{SE}, \mathrm{n}=30)$, and photon flux reached 169.2 to $606.7 \mu \mathrm{mol} \mathrm{m} \mathrm{m}^{-2} \mathrm{~s}^{-1}$ $(430.5 \pm 27.7, \mathrm{n}=30)$. At these high irradiance levels, light was unlikely to limit eelgrass growth during the experiment (Dennison \& Alberte 1985).

Experimental design. In a factorial field experiment, we tested whether shoot growth and increase in shoot density within colonizing seagrass patches are affected by sediment nutrient levels and plant density. The factor 'Nutrients' had 3 levels: (1) artificial fertilization with a slow-release (NPK-) fertilizer, (2) fertilization through biodeposition of transplanted mussels Mytilus edulis and (3) unfertilized controls. The factor 'Density' had 2 levels (Fig. 1): high (19 shoots, distance between shoots $20 \mathrm{~cm}$ ) and low (7 shoots, distance between shoots $40 \mathrm{~cm}$ ). The 2 factors were combined in an orthogonal design with 6 treatments, each replicated 4 times in a randomized block design with 24 plots and 312 individual Zostera shoots. Shoots were collected on 12 and 13 May from various large patches $(>5 \mathrm{~m}$

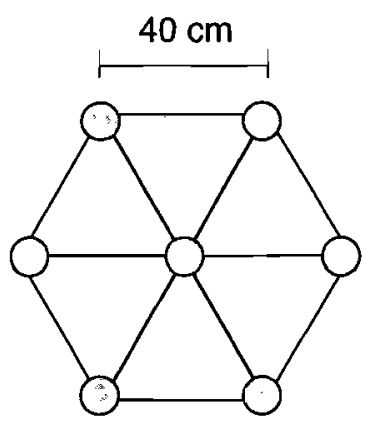

Low density

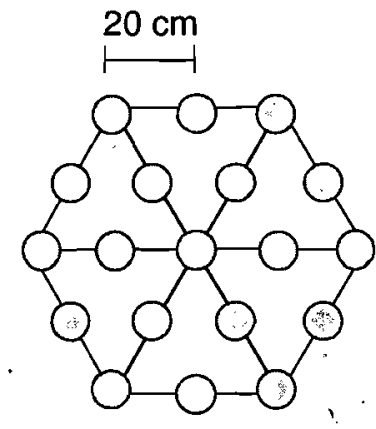

High density
Fig. 1. Experimental design. Single Zostera marina shoots (gray circles) were planted at low and high densities, equidistantly placed in circular plots. Each density treatment was combined with 1 of 3 nutrient treatments: (1) sediment fertilization with a slow-release fertilizer, (2) sediment fertilization through biodeposition from transplanted mussels or (3) untreated control $(n=4)$ 
diameter) in an extensive eelgrass meadow $1 \mathrm{~km}$ north of Friedrichsort. We selected only terminal non-fertile plants of 30 to $50 \mathrm{~cm}$ length from the end of rhizomes to provide homogeneous material. Rhizome length was restricted to $5 \mathrm{~cm}$ in all transplants. The shoots were stored in seawater for a maximum of $2 \mathrm{~h}$ before replanting at our experimental site. Rhizomes were located at ca 5 to $10 \mathrm{~cm}$ sediment depth. A U-shaped plastic-covered wire guaranteed an initial anchoring while the plant developed a fully grown rhizome. Most wires were lost after some months, but loss of shoots seemed very small as root systems were regenerated within $<1$ mo. Initial mortality of transplants was $<1 \%$ after $8 \mathrm{~d}$. Plants were arranged in circular plots in a way such that each plant had a defined distance to each neighbor, corresponding to the 2 density treatments (Fig. 1). We chose circular plots because they mimic the shape of natural seagrass patches and minimize edge effects in contrast to square-shaped plots. The plots had an initial diameter of $80 \mathrm{~cm}\left(0.5 \mathrm{~m}^{2}\right.$ area) and were located within $3 \mathrm{~m}$ distance of each other to avoid interaction. Prior to transplantation the experimental area $(15 \times 30 \mathrm{~m})$ was cleared of rare mussel clumps and smaller eelgrass patches ( 1 to 10 shoots). Other eelgrass patches were present and abundant in the vicinity of the experimental area.

For sediment nutrient enrichment we used slowrelease fertilizer pellets (Plantacote Depot, Urania Agrochem, Hamburg, Germany), containing $14 \% \mathrm{~N}$ $\left(5.7 \% \mathrm{NO}_{3}^{-}\right.$and $8.3 \% \mathrm{NH}_{4}{ }^{+}$), $9 \% \mathrm{P}_{2} \mathrm{O}_{5}$ and $15 \% \mathrm{~K}_{2} \mathrm{O}$ (detailed comparisons of this and other methods for in situ nutrient enrichment are given in Worm et al. 2000). Pellets had a polyurethane membrane which controls nutrient release ( 4 to $8 \mathrm{mo}$ in soil). We used a 4 and an 8 mo fertilizer, each with a total dose of $150 \mathrm{~g}$ $\mathrm{N}$ and $110 \mathrm{~g} \mathrm{P} \mathrm{m}^{-2}$. Three days prior to eelgrass transplantation the 4 mo fertilizer was gently massaged into the sediment between 0 and $6 \mathrm{~cm}$ depth within 8 randomly assigned plots, carefully avoiding mechanical damage of the root/rhizome system. After 3 mo the procedure was repeated with the $8 \mathrm{mo}$ fertilizer. In the second half of the experiment we used this 'slower' fertilizer to achieve slightly slower release and more gradual enrichment. As a procedural control, plots without fertilizer were mechanically treated the same way as fertilized plots. As a second enrichment treatment, mussel clumps collected at the site were added to 8 randomly assigned plots, in such a way that a 5 to $10 \mathrm{~cm}$ layer of live mussels covered $100 \%$ of the plot's surface. Mussel cover was checked monthly and maintained at initial density throughout the experiment.

We quantified Zostera shoot growth, increase in shoot density and percent coverage as the dependent variables. Shoot growth rates were measured nondestructively and in situ using a leaf-marking tech- nique according to Ziemann (1974) modified after Williams \& Ruckelshaus (1993). On 13 May, 30 June and 8 August in each plot, 3 to 5 randomly selected shoots were marked by pushing a syringe needle through the shoot in the area of the non-growing leaf sheath. After 6 to $11 \mathrm{~d}$, leaf elongation of each leaf was determined in situ by measuring the distance between the marking of each leaf and the one on the non-growing leaf sheath to the nearest millimeter. Growth rates ( $\mathrm{mm}$ shoot ${ }^{-1} \mathrm{~d}^{-1}$ ) were calculated by adding measured increases in leaf length for all leaves of a shoot and dividing by the number of days. Shoot density per plot was measured in June, August and November. Rates of increase in shoot density were calculated following an exponential model, with $\mathrm{r}=\left(\ln N_{2}-\ln N_{1}\right) /\left(t_{2}-t_{1}\right)$, where $N$ is the number of shoots and $t$ is time in days. This formula has been proven useful to model increase in shoot density in Zostera population studies (Olesen \& Sand-Jensen 1994b). Percent cover of eelgrass was measured 6 mo after transplanting using a $1 \times 1 \mathrm{~m}$ frame with a $10 \times 10 \mathrm{~cm}$ grid. Grids with live Zostera present were counted as $1 \%$ cover for each grid. For statistical comparison, cover data were corrected for different initial coverage by dividing percent cover by initial density ( 7 shoots in low-density plots, 19 shoots in high-density plots).

To quantify sediment nutrient enrichment levels, we sampled sediment porewater in all experimental plots monthly from 13 May to 28 September. Samples were obtained with $10 \mathrm{ml}$ plastic syringes. A plastic tip was perforated several times and wrapped with $20 \mu \mathrm{m}$ mesh gauze. At 3 randomly chosen points per plot, syringes were inserted $5 \mathrm{~cm}$ into the substratum, using a new syringe for each subsample. The chosen depth horizon ( 3 to $6 \mathrm{~cm}$ ) lies within the zone of densest root/rhizome development. Samples were cooled on board the dive boat and deep frozen 1 to $2 \mathrm{~h}$ afterwards. Since the concentration of $\mathrm{NH}_{4}{ }^{+}$in the porewater is generally $>20 \mu \mathrm{mol} 1^{-1}$, changes in concentration due to freezing were considered non-significant. Samples were diluted 1:5 with distilled water and analyzed for dissolved ammonium and soluble reactive phosphate after Grasshoff et al. (1986). To reveal effects of nutrient washout by wave action, water column samples were taken in June and July; $50 \mathrm{ml}$ syringes were filled in 10 to $15 \mathrm{~cm}$ height above 3 randomly selected plots for each fertilization treatment (fertilizer, mussels, controls].

Data analysis. Most dependent variables were analyzed by $(2 \times 3)$ factorial ANOVA with 'Density' and 'Nutrients' as independent variables. The spatial block effect (Blocks 1 to 4 ) was included as a non-interactive variable in order to remove variance caused by possible spatial gradients. Initially, we used repeated-measure (RM)-ANOVA models, because we had sampled the 
same plots repeatedly. When significant Time $\times$ Treatment interactions were detected, we analyzed each sampling date separately. Water column nutrient data were analyzed by $(2 \times 3)$ factorial ANOVA with 'Time' and 'Nutrients' as independent variables, because we sampled different plots at the 2 sampling dates, thus these results were independent. Student-NewmanKeuls (SNK) procedure was used for post hoc comparisons. Differences of $\mathrm{p}<0.05$ are described as significant $_{i}$ differences $0.05<p<0.1$ are described as trends. Percent variance explained $\left(\left[S S_{\text {factor }} / S S_{\text {total }}\right] \times 100\right)$ was calculated to reveal the relative importance of the experimental factors. This was done separately for between-subject factors ('Density' and 'Nutrients' and their interaction) and within-subject factors ('Time' and its interactions with 'Density' and 'Nutrients'). Untransformed growth and cover data met the assumption of homogeneity of variances (Cochran's test). Nutrient data were log-transformed.

\section{RESULTS}

Application of fertilizer and mussels both increased porewater nutrient levels throughout the experimental period (Table 1). Background nutrient levels were relatively low, with an average of $24.0 \mu \mathrm{mol} \mathrm{l}^{-1} \mathrm{NH}_{4}{ }^{+}$and $5.2 \mu \mathrm{mol} \mathrm{l}^{-1} \mathrm{PO}_{4}{ }^{3-}$, corroborating earlier results from Friedrichsort and an additional site (Reusch et al. 1994). Enrichment effects were significant for ammonium (RM-ANOVA, $F_{2,15}=27.7, \mathrm{p}<0.0001$ ) and phosphate (RM-ANOVA, $F_{2,9}=12.4, \mathrm{p}=0.0026$ ). The NPK-fertilizer increased ammonium availability between 47 and $1729 \%$ (mean $493 \%$ ) and phosphate availability between 62 and $1151 \%$ (mean $411 \%$ ). Pronounced temporal variability in nutrient concentrations in enriched plots is probably caused by declining release and exhaustion of fertilizer after 2 mo (Worm et al, 2000). Mussels increased ammonium levels between 55 and $112 \%$ (mean $67 \%$ ) and phosphate between 10 and $82 \%$ (mean $76 \%$ ); however, the latter effect was not significant (SNK, $\mathrm{p}>0.1$ ). In addition, the fertilizer and mussels tended to increase water column $\mathrm{NH}_{4}{ }^{+}$levels above the experimental plots (ANOVA, $F_{2,12}=3.6, \mathrm{p}=0.061$ ). Water column phosphate levels tended to be elevated by the fertilizer (ANOVA, $F_{2,12}=3.3, \mathrm{p}=0.074$ ) but not by mussels (SNK, p > 0.1; Table 1).
Surprisingly, this increase in nutrient availability had only minor effects on eelgrass leaf growth, increase in shoot density and patch expansion, while increased plant density had positive effects on all response variables, explaining between 18 and $47 \%$ of total variance across the growth period (Table 2, but note that effects on shoot addition only represent a trend at $p=0.078$ ). These results contradict both of our initial hypotheses, nutrient limitation and density-dependent competition and provide evidence for facilitation among Zostera shoots in colonizing patches.

Average leaf elongation rates were very high, between $31.7 \mathrm{~mm}$ shoot ${ }^{-1} \mathrm{~d}^{-1}$ in May and $54.6 \mathrm{~mm} \mathrm{shoot}^{-1}$ $\mathrm{d}^{-1}$ in July with a maximum of $74.9 \mathrm{~mm}$ shoot $^{-1} \mathrm{~d}^{-1}$. On average, shoot growth rates were significantly higher in the high-density plots (Fig. 2, Table 2A), with strongest effects in July (13\% increase), weaker effects ( $9 \%$ increase) in August and a non-significant decrease in May (6\%). When ammonium availability in the mussel plots peaked in July (Table 1), there was a trend of increased shoot growth in high-density patches with mussels but not in low-density patches (Fig. 2, ANOVA, Nutrients $\times$ Density, $F_{2,15}=3.3, \mathrm{p}=0.063$ ).

Average shoot density increased gradually from 38 to $150 \mathrm{~m}^{-2}$ (4-fold) in high-density plots and from 14 to $35 \mathrm{~m}^{-2}$ (2.5-fold) in low-density patches (Fig. 2B). Differences between density treatments were significant throughout the experiment (ANOVA, $p<0.01$ ), but this result is trivial given the initial difference in shoot densities. To provide meaningful comparisons among the different density treatments we calculated relative shoot addition rates (see 'Methods'). Shoot addition rates tended to be increased in high-density patches (Fig. 3, $p=0.078$, Table 2B), with significant effects in

Table 1. Ammonium and phosphate concentrations ( $\mu \mathrm{mol}^{-1}$, mean $\pm 1 \mathrm{SE}, \mathrm{n}=8$ ) in response to nutrient enrichment

\begin{tabular}{|c|c|c|c|c|c|c|c|}
\hline Variable & Date & Control & $1 \mathrm{SE}$ & Fertilizer & r SE & Mussels & $S \mathrm{SE}$ \\
\hline \multicolumn{8}{|c|}{ Sediment porewater } \\
\hline \multirow[t]{5}{*}{$\mathrm{NH}_{4}^{+}$} & 13 May & 24.10 & 4.11 & 53.81 & 6.34 & 29.31 & 5.45 \\
\hline & 9 Jun & 21.03 & 1.63 & 384.79 & 112.14 & 44.54 & 7.71 \\
\hline & $11 \mathrm{Jul}$ & 29.94 & 4.05 & 55.05 & 17.43 & 50.76 & 4.63 \\
\hline & 14 Aug & 21.24 & 2.85 & 123.18 & 47.10 & 37.73 & 14.50 \\
\hline & $28 \mathrm{Sep}$ & 23.74 & 4.18 & 34.93 & 5.87 & 36.91 & 11.71 \\
\hline \multirow[t]{5}{*}{$\mathrm{PO}_{4}{ }^{3-}$} & 13 May & 1.34 & 0.40 & 2.17 & 0.45 & 1.09 & 0.27 \\
\hline & 9 Jun & 5.14 & 0.25 & 64.33 & 16.63 & 7.49 & 1.02 \\
\hline & $11 \mathrm{Jul}$ & 5.39 & 0.94 & 21.07 & 5.89 & 8.25 & 1.52 \\
\hline & 14 Aug & 8.11 & 0.86 & 40.89 & 17.72 & 8.92 & 1.06 \\
\hline & 28 Sep & 5.84 & 1.26 & 14.40 & 2.27 & 8.58 & 3.67 \\
\hline \multicolumn{8}{|c|}{ Water column } \\
\hline \multirow{2}{*}{$\mathrm{NH}_{4}^{+}$} & 9 Jun & 0.77 & 0.08 & 1.44 & 0.25 & 1.39 & 0.25 \\
\hline & $11 \mathrm{Jul}$ & 1.20 & 0.28 & 0.94 & 0.10 & 2.05 & 0.60 \\
\hline \multirow[t]{2}{*}{$\mathrm{PO}_{4}{ }^{3-}$} & 9 Jun & 0.25 & 0.04 & 0.38 & 0.06 & 0.20 & 0.05 \\
\hline & $11 \mathrm{Jul}$ & 0.10 & 0.03 & 0.18 & 0.05 & 0.18 & 0.03 \\
\hline
\end{tabular}


Table 2. ANOVA. Effects of plant density and nutrient enrichment on performance of Zostera marina. Repeated-measure-ANOVA results are presented when more than 1 date was sampled. Mean squares for shoot addition rates were multiplied by $10^{5}$

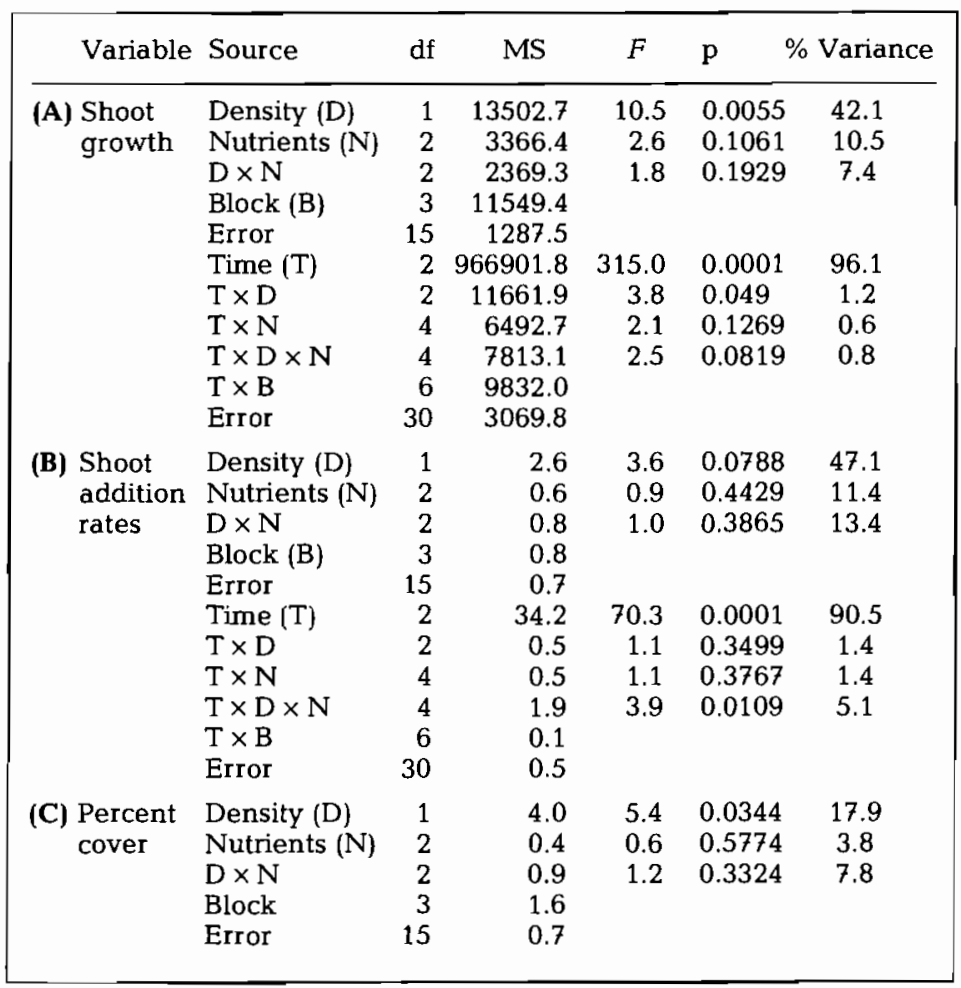
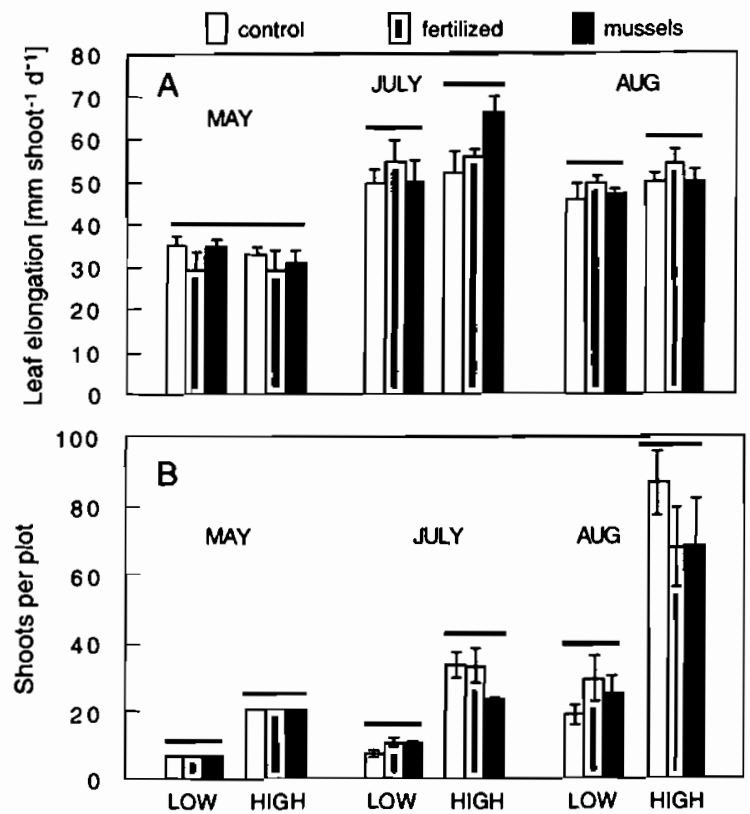

Fig. 2. (A) Zostera marina shoot growth rates, measured as leaf elongation shoot ${ }^{-1} \mathrm{~d}^{-1}$. LOW and HIGH: plant density treatments, shading: nutrient treatments. (B) Zostera marina shoot density in the 6 experimental treatments. Data are means \pm 1 SE. See Table 1 for nutrient levels. Horizontal bars separate those treatments which are significantly different at $p<0.05$ (see Table 2A for ANOVA results)

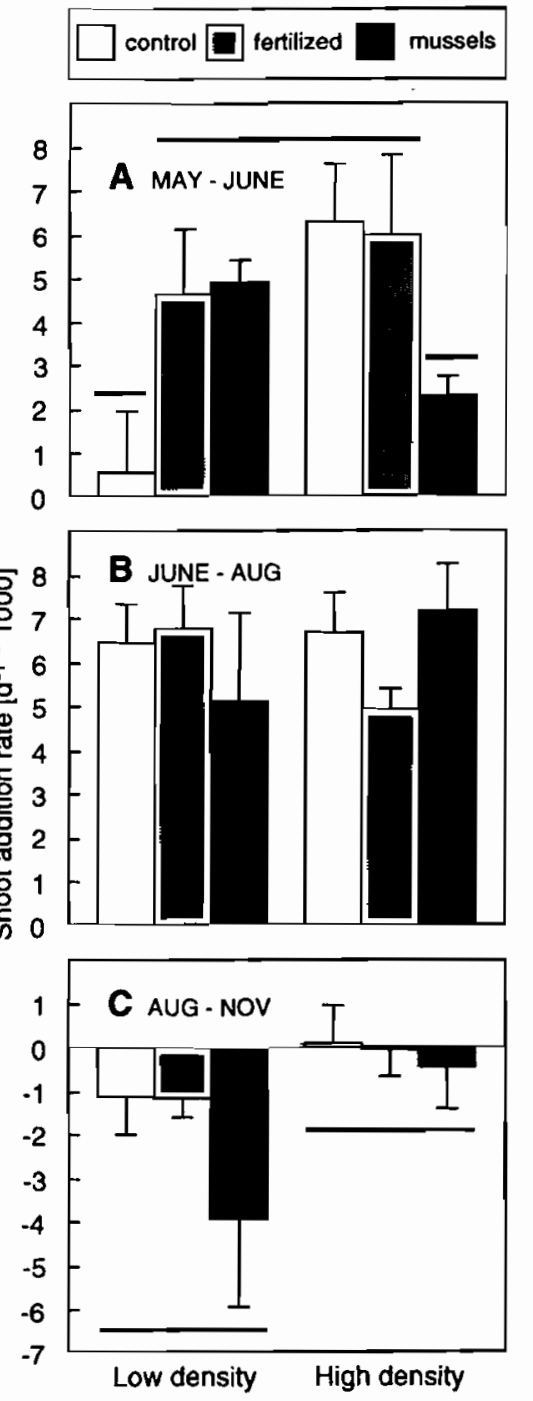

Fig. 3. Zostera marina shoot addition rates, measured as daily increase of shoots per plot. Symbols as in Fig. 2. No significant differences between treatments occurred in June to August. See Table 2B for data analysis

fall (Fig. 3C, ANOVA, Density, $F_{1,15}=5.1, \mathrm{p}=0.039$ ). In spring, a significant Nutrient $\times$ Density interaction was detected (Fig. 3A, ANOVA, Density $\times$ Nutrients, $F_{2,15}=4.8, \mathrm{p}=0.025$ ). Shoot density increased in fertilized and mussel plots at low initial density, but did not change, or decreased, in high-density patches (Fig. 3A). These time-dependent interactions resulted in a significant 3-way interaction in the repeated-measures model $(\mathrm{T} \times \mathrm{D} \times \mathrm{N}$, Table $2 \mathrm{~B})$.

Eelgrass percent coverage at the end of the growth period was strongly increased in high-density treatments (Fig. 4). This effect remained significant after correction for different initial coverage (Table 2C). Nutrients had no significant effect on eelgrass coverage (Table 2C). Observations throughout the winter 


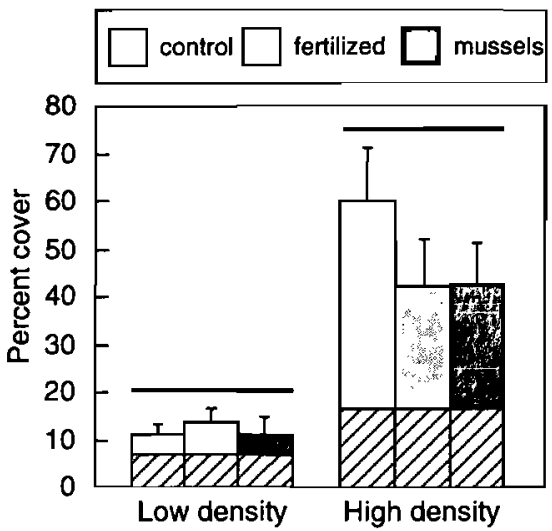

Fig. 4. Zostera marina plant coverage (within a $1 \times 1 \mathrm{~m}$ grid) at the end of the experimental period in November. Hatched areas indicate initial coverage at the start of the experiment.

Symbols as in Fig. 2. See Table $2 \mathrm{C}$ for data analysis

indicated little change in eelgrass coverage until February, when the experiment was terminated by a series of severe winter storms which destroyed most patches, regardless of size and density.

\section{DISCUSSION}

These results show that during the early stages of colonization high-density patches of eelgrass perform better than low-density patches and that sediment nutrient availability is not necessarily a major factor that drives eelgrass performance and colonization rates. Facilitation among eelgrass shoots within colonizing patches appears to be more important than competitive processes during colonization and patch formation. We conclude that restoration efforts through transplantation should aim for high initial plant density and patch size in order to exploit facilitation among shoots and increase restoration success.

\section{Density effects}

With higher initial shoot density per patch we found significantly higher shoot growth and shoot addition rates which resulted in 4 -fold shoot density and percent cover differences among high- and low-density plots after 6 mo. This gives evidence for positive intraspecific effects on both the individual shoot and population levels and no evidence for density-dependent competition in this artificially created eelgrass population. Positive effects of increasing patch size have been proposed by other workers (Duarte \& SandJensen 1990, Olesen \& Sand-Jensen 1994a) and are probably linked to reduction of current velocity (Fon- seca et al. 1982), sediment stabilization and physiological integration among the shoots (Olesen \& SandJensen 1994a). In our experiment, the strongest positive effects of the high-density treatment were found in fall, when shoot density declined in low-density patches but remained stable in high-density patches. This was probably caused by physical disturbance of fall storms. Intense winter storms, however, severely damaged all treatments and effectively terminated the experiment. It may be that patch size needs to be significantly greater than what we established in order to restore and maintain shallow-water populations in the face of intense disturbances. Similarly, Olesen \& Sand-Jensen (1994a) found Zostera patch mortality to be restricted to newly recruited patches with $<32$ shoots, which was interpreted as due to lack of mutualistic protection. In a restoration experiment similar to ours, Sheridan et al. (1998) found that seagrass (Halodule wrightii) survival, coverage and new shoot density was increased by high plant density. Positive effects of plant density on seagrass colonization appear to be similar across different regions and species. Intra- and interspecific facilitation, mediated through mitigation of physical stress and disturbance, also prevail among saltmarsh macrophytes (Bertness \& Shumway 1993).

\section{Nutrient effects}

Despite relatively low porewater and water column nutrient levels, we found little evidence for nutrient limitation of Zostera in this experiment. Application of mussels and slow-release NPK-fertilizer increased porewater nutrient levels 1.6 to 5 -fold over the experimental period, but this had very limited effects on Zostera performance. From May to June, shoot addition rate increased in fertilized low-density but not in highdensity patches. Similar effects were found in mussel patches (Fig. 3A). In addition, shoot growth rates tended to be higher in high-density mussel plots in July, but were not affected at other times or by other modes of fertilization (Fig. 2). Reusch et al. (1994) found significant effects of a Mytilus edulis understorey on the leaf length and width of Zostera. The magnitude of effects between these 2 investigations is similar: Reusch et al. (1994) found $32 \%$ increase in leaf length, while we measured $27 \%$ higher leaf elongation rates in mussel plots in July. This may give some additional evidence for an interspecific facilitation between Zostera shoots and M. edulis (Reusch et al. 1994). However, fertilization effects on Zostera were not constant through time and depended on plant density treatments. The reason for these weak time- and density-dependent nutrient effects remains speculative (see below). Using an identical method for the estimation of Zostera shoot growth 
rates in a North Pacific intertidal population with saturating light and nutrient supply, Williams \& Ruckelshaus (1993) found leaf elongation rates between 2.7 and $3.6 \mathrm{~cm}_{\text {shoot }}{ }^{-1} \mathrm{~d}^{-1}$ in May and August, respectively. The rates we measured in our Baltic population were twice as high. High growth rates and an apparent lack of severe nutrient limitation at relatively low ambient nutrient porewater concentrations $\left(<30 \mu \mathrm{mol} \mathrm{NH}_{4}{ }^{+} \mathrm{l}^{-1}\right)$ contrast with other eelgrass fertilization studies, which found growth responses to fertilization over a range of sediment ammonium background concentrations from 1 to $100 \mu \mathrm{mol} \mathrm{NH}{ }_{4}{ }^{-1}{ }^{-1}$ (Dennison et al. 1987, reviewed by Short 1987, Worm et al. 2000). A lack of response to fertilization in our study could be indicative of (1) other factors limiting eelgrass growth or (2) low nutrient demand in this Baltic population. Among other factors, light limitation at the experimental depth $(2 \mathrm{~m})$ can probably be ruled out, as light fluxes were above saturation levels over the entire experimental period (see 'Methods'). Epiphyte shading can also reduce eelgrass productivity (Neckles et al. 1993, Williams \& Ruckelshaus 1993). We observed high epiphyte loads (mostly Ectocarpus siliculosus and diatoms) on eelgrass shoots in May and June. In these months, epiphytes may have reduced leaf eelgrass growth (Fig. 2) and possibly masked positive nutrient effects. However, epiphyte loads were low from July to November and unlikely to explain lacking nutrient response in Zostera. Grazing has been proposed as another potentially limiting factor in seagrass beds (Valentine \& Heck 1991, Wolken 1994). We controlled Zostera plants for grazing marks throughout our experiment but found no evidence to support this hypothesis. High growth rates and lack of nutrient limitation at low nutrient levels thus seem to be indicative of low nutrient demand in this Zostera population. Recently, it was shown that pronounced genetic differentiation occurs in Zostera even over relatively short geographic distances (Ruckelshaus 1998, Reusch et al. 2000). We hypothesize that these differences may extend to physiologically relevant parameters, such as nutrient demand and growth response.

Acknowledgements. We are grateful for field assistance by K. Mellentin and G. Lotter and logistical support by T. Kollatschni. We thank B. Schaffelke for providing the photon flux data. H. K. Lotze and A. F. Peters provided helpful comments on earlier drafts of this manuscript. This study was partly funded by the Ministry of Environment, Schleswig-Holstein. We are grateful to the Navy at Friedrichsort (WTD 71) for granting access to the restricted area.

\section{LITERATURE CITED}

Bertness MD, Shumway SW (1993) Competition and facilitation in marsh plants. Am Nat 142:718-724
Ciszewski P, Kruk-Dowgiallo L, Andrulewicz E, Radziejewksa $T$ (1991) A study on pollution of the Puck Lagoon and possibility of restoring the lagoon's original ecological state. Acta Ichthyol Pisca 21:29-37

den Hartog C (1970) The seagrasses of the world. NorthHolland, Amsterdam

Dennison WC, Alberte RS (1985) Role of daily light period in the depth distribution of Zostera marina (eelgrass). Mar Ecol Prog Ser 25:51-61

Dennison WC, Aller RC, Alberte RS (1987) Sediment ammonium availability and eelgrass (Zostera marina) growth. Mar Biol 94:469-477

Duarte CM, Sand-Jensen K (1990) Seagrass colonization: patch formation and patch growth in Cymodocea nodosa. Mar Ecol Prog Ser 65:193-200

Fenner M (ed) (1992) Seeds - the ecology of regeneration in plant communities. $\mathrm{CAB}$ International, Wallingford, Oxon

Fonseca MS, Fisher JS, Zieman JC, Thayer GW (1982) Influence of seagrass, Zostera marina L., on current flow. Estuar Coast Shelf Sci 15:351-364

Giesen WBJT, van Katwijk MM, den Hartog C (1990) Eelgrass condition and turbidity in the Dutch Wadden Sea. Aquat Bot 37:71-85

Grasshoff K, Ehrhardt M, Kremling K (1986) Methods of seawater analysis. Verlag Chemie, Weinheim

Harwell MC, Orth RJ (1999) Eelgrass (Zostera marina L.) seed protection for field experiments and implications for largescale restoration. Aquat Bot 64:51:-61

HELCOM (Helsinki Commission) (1996) Third periodic assessment of the state of the marine environment of the Baltic Sea, 1986-93: background document. Baltic Sea environment proceedings, No 64B, Helsinki Commission

Kenworthy WJ, Fonseca MS (1992) The use of fertilizer to enhance growth of transplanted seagrasses Zostera marina L. and Halodule wrightii Aschers. J Exp Mar Biol Ecol 163: $141-161$

Lotze HK, Worm B, Sommer U (2000) Propagule banks, herbivory and nutrient supply control population development and dominance patterns in macroalgal blooms. Oikos 89: $46-58$

Neckles HA, Wetzel RL, Orth RJ (1993) Relative effects of nutrient enrichment and grazing on epiphyte-macrophyte (Zostera marina) dynamics. Oecologia 93:285-295

Olesen B, Sand-Jensen K (1994a) Patch dynamics of eelgrass Zostera marina. Mar Ecol Prog Ser 106:147-156

Olesen B, Sand-Jensen K (1994b) Demography of shallow eelgrass (Zostera marina) populations-shoot dynamics and biomass development. J Ecol 82:379-390

Orth RJ (1992) A perspective on plant-animal interactions in seagrasses: physical and biological determinants influencing plant and animal abundance. In: John DM, Hawkins SJ, Price JH (eds) Plant-animal interactions in the marine benthos. The Systematics Association Special Volume 46. Clarendon, Oxford, p 147-164

Orth RJ, Moore KA (1983) Chesapeake Bay: an unprecedented decline in submerged aquatic vegetation. Science 222 : $51-53$

Orth RJ, Luckenbach M, Moore KA (1994) Seed dispersal in a marine macrophyte: implications for colonization and restoration. Ecology 75:1927-1939

Orth RJ, Harwell MC, Fishman JR (1999) A rapid and simple method for transplanting eelgrass using single, unanchored shoots. Aquat Bot 64:77-85

Reusch TBH, Chapman ARO, Gröger JP (1994) Blue mussels Mytilus edulis do not interfere with eelgrass Zostera marina but fertilize shoot growth through biodeposition. Mar Ecol Prog Ser 108:265-282 
Reusch TBH, Stam WT, Olsen JL (2000) A microsatellite-based estimation of clonal diversity and population subdivision in Zostera marina, a marine flowering plant. Mol Ecol 9: $127-140$

Ruckelshaus $\mathrm{MH}$ (1998) Spatial scale of genetic structure and an indirect estimate of gene flow in eelgrass, Zostera marina. Evolution 52:330-343

Sheridan P, McMahan G, Hammerstrom K, Pulich W Jr (1998) Factors affecting restoration of Halodule wrightii to Galveston Bay, Texas. Restor Ecol 6:144-158

Short FT (1987) Effects of sediment nutrients on seagrass: literature review and mesocosm experiments. Aquat Bot $27: 41-57$

Short FT, Wyllie-Escheverria S (1996) Natural and humaninduced disturbance of seagrasses. Environ Conserv 25: $17-27$

Valentine JF, Heck KLH Jr (1991) The role of sea urchin grazing in regulating subtropical seagrass meadows: evidence from field manipulations in the northern Gulf of Mexico. J Exp Mar Biol Ecol 154:215-230

Williams SL (1987) Competition between the seagrasses Tha-

Editorial responsibility: Otto Kinne (Editor),

Oldendorf/Luhe, Germany lassia testudinum and Syringodium filiforme in a Caribbean lagoon. Mar Ecol Prog Ser 35:91-98

Williams SL, Ruckelshaus MH (1993) Effects of nitrogen availability and herbivory on eelgrass (Zostera marina) and epiphytes. Ecology 74:904-918

Wolken K (1994) Grazing in Seegraswiesen. MSc thesis, University of Kiel

Worm B, Chapman ARO (1998) Relative effects of elevated grazing pressure and competition by a red algal turf on two post-settlement stages of Fucus evanescens C. Ag. J Exp Mar Biol Ecol 220:247-268

Worm B, Lotze HK, Boström C, Engkvist R, Labanauskas V, Sommer U (1999) Marine diversity shift linked to interactions among grazers, nutrients and dormant propagules. Mar Ecol Prog Ser 185:309-314

Worm B, Reusch TBH, Lotze HK (2000) In situ nutrient enrichment: methods for marine benthic ecology. Int Rev Hydrobiol 85:359-375

Ziemann JC (1974) Methods for the study of the growth and production of turtle grass, Thalassia testudinum König. Aquaculture 4:139-143

Submitted: October 18, 1998; Accepted: February 1, 2000 Proofs received from author(s): June 13, 2000 